\title{
Forecasting the development of boreal paludified forests in response to climate change: a case study using Ontario ecosite classification
}

Benoit Lafleur ${ }^{1,2^{*}}$, Nicole J Fenton ${ }^{1}$ and Yves Bergeron ${ }^{1}$

\begin{abstract}
Background: Successional paludification, a dynamic process that leads to the formation of peatlands, is influenced by climatic factors and site features such as surficial deposits and soil texture. In boreal regions, projected climate change and corresponding modifications in natural fire regimes are expected to influence the paludification process and forest development. The objective of this study was to forecast the development of boreal paludified forests in northeastern North America in relation to climate change and modifications in the natural fire regime for the period 2011-2100.
\end{abstract}

Methods: A paludification index was built using static (e.g. surficial deposits and soil texture) and dynamic (e.g. moisture regime and soil organic layer thickness) stand scale factors available from forest maps. The index considered the effects of three temperature increase scenarios (i.e. $+1^{\circ} \mathrm{C},+3^{\circ} \mathrm{C}$ and $+6^{\circ} \mathrm{C}$ ) and progressively decreasing fire cycle (from 300 years for 2011-2041, to 200 years for 2071-2100) on peat accumulation rate and soil organic layer (SOL) thickness at the stand level, and paludification at the landscape level.

Results: Our index show that in the context where in the absence of fire the landscape continues to paludify, the negative effect of climate change on peat accumulation resulted in little modification to SOL thickness at the stand level, and no change in the paludification level of the study area between 2011 and 2100 . However, including decreasing fire cycle to the index resulted in declines in paludified area. Overall, the index predicts a slight to moderate decrease in the area covered by paludified forests in 2100, with slower rates of paludification.

Conclusions: Slower paludification rates imply greater forest productivity and a greater potential for forest harvest, but also a gradual loss of open paludified stands, which could impact the carbon balance in paludified landscapes. Nonetheless, as the thick Sphagnum layer typical of paludified forests may protect soil organic layer from drought and deep burns, a significant proportion of the territory has high potential to remain a carbon sink.

Keywords: Boreal forest; Canada; Carbon sequestration; Paludification; Peat forests; Forest harvest

\section{Background}

In boreal forest ecosystems, successional paludification is described as a dynamic process driven by forest succession between fire events that leads to peat accumulation, and a concomitant thickening of the soil organic layer (SOL), and the formation of waterlogged conditions on a formerly dry mineral soil (Simard et al. 2007).

\footnotetext{
* Correspondence: benoit.lafleur@uqat.ca

${ }^{1}$ Institut de recherche sur les forêts, Université du Québec en

Abitibi-Témiscamingue, 445 boul. de I'Université, Rouyn-Noranda, QC J9X 5E4, Canada

${ }^{2}$ Centre d'étude de la forêt, Université du Québec à Montréal, 141 Avenue du Président-Kennedy, Montréal, QC H2X 1Y4, Canada
}

Paludification is influenced by climatic factors and permanent site features, such as surficial deposits and soil texture, as well as by natural fire regimes (Lecomte et al. 2006; Simard et al. 2009; Payette et al. 2013). In boreal regions, in the extended absence of fire, paludification leads to the formation of paludified forests and can reduce forest productivity by up to $50 \%-80 \%$ (Simard et al. 2007).

According to the most recent report of the Intergovernmental Panel on Climate Change, warming of the climate system is unequivocal (IPCC 2013). This changing climate is expected to increase drought severity in boreal regions (Girardin and Mudelsee 2008), and therefore to

\section{苗}


influence the natural fire regime, resulting in an increase of fire severity and burn rate (Flannigan et al. 2005; de Groot et al. 2009; Bergeron et al. 2010; van Bellen et al. 2010). Fire plays an important role in landscape level paludification processes, as fire can "depaludify" forest stands if most of the SOL is burnt (Dyrness and Norum 1983; Greene et al. 2005). However, if the fire is not severe and a relatively thick SOL remains after fire, the regenerating forest stands may remain paludified (Lecomte et al. 2005). Because boreal peatlands represent important carbon reservoirs (it is estimated that boreal peatlands, including paludified forests, store $455 \mathrm{Pg}$ of carbon, i.e. approximately $15 \%$ of the Earth's terrestrial carbon (Gorham 1991; Lavoie et al. 2005)) any modification to the fire cycle may have important consequences on the carbon cycle and the global climate.

Throughout the boreal region, paludified forests support important forest industries. It is expected that any modifications to the climate and natural fire regimes will, in all likelihood, require industries to adapt to new ecosystem conditions and, presumably, to modify their practices. Depending on the type of harvest practices, forest harvest in paludified forests can both promote or reduce paludification (Lafleur et al. 2010a, 2010b), and, as is the case for fire, have important effects on the $\mathrm{C}$ budget at the landscape level. This context provides strong incentives for the development of simple tools that can be used to rapidly and easily forecast the combined effects of climate change and modified fire regime on paludification and forest development.

In North America, forest mapping is commonly used to describe the forest mosaic at the regional scale. Forest maps provide information on stand scale environmental factors (e.g. surficial deposits, soil texture, moisture regime, slope), as well as on stand species composition, height and density. This information presents a great potential for research in forest ecology and management. For instance, it can be used by forest managers to forecast the effects of silvicultural practices or wildfire on stand regeneration, composition and productivity. Because some stand scale environmental factors provided in forest maps are intrinsically dynamic (e.g. soil moisture regime and SOL thickness) and potentially influenced by climate variables, forest maps could also be used to forecast the effects of climate change on forest development.

In this context, the main objective of this study was to use information commonly available on forest maps in Canada in order to evaluate the potential for paludification of boreal forest stands in relation to climate change and modifications to the natural fire regime. To achieve this objective we developed a dynamic paludification index. First, we developed a base index projecting the development of paludified forests over time without considering climate change. Then, we added the effects of climate change on the thickening on SOL to this base index in order to forecast the development of paludified forests in response to projected climate change. Finally, forecasted climate change and modifications to the natural fire regime were added to the base index to further explore the development of paludified forests in the context of climate change. Based on information commonly available on forest maps, the paludification index can therefore estimate the effects of both climate change and natural fire regimes on the development of paludified forests at both the local and regional scales.

\section{Methods}

\section{Study area}

A territory in eastern Canada was used to model the development of paludified forests in relation to climate change and changes in the natural fire regime. The Gordon Cosens Forest is a $20000 \mathrm{~km}^{2}\left(17360 \mathrm{~km}^{2}\right.$ of which is covered in forest, and the remaining area is water bodies) forest management unit located in the Ontario ecodistrict 3E-1, a region also known as the Clay Belt (Figure 1). Cold climate, flat topography, and surficial deposits that are resistant to water penetration all make this region favorable for the development of paludified forests (Jeglum 1991; Riley 1994). The southern part of the Clay Belt is covered by thick $(>10 \mathrm{~m})$ glaciolacustrine clay and silt deposited by glacial Lake Ojibway, while the northern part, known as the Cochrane till, is covered by a compact till made up of a mixture of clay and gravel, created by a southward ice flow approximately 8000 years BP (Veillette 1994). Soils of the study area are mostly classified as Gleysols and Luvisols (Soil Classification Working Group 1998). Nonetheless, organic deposits (i.e. a surficial deposit consisting of a SOL $>40 \mathrm{~cm}$ thick) are found in many locations in both the southern and northern parts of the study area. Black spruce (Picea mariana [Mill.] BSP.) is the dominant tree species of the study area.

According to the local weather station (Kapuskasing, Ontario), from 1981 to 2010, the average annual temperature was $1.3^{\circ} \mathrm{C}$ and the average annual precipitation was $830 \mathrm{~mm}$, with 30\% falling during the growing season (Environment Canada 2014). The average number of degree-days $\left(>5^{\circ} \mathrm{C}\right)$ is 1430 , and the frost-free season lasts about 100 days; frost can occasionally occur during the growing season. In this region, according to different scenarios (A1 and B2) and simulation models (Canadian Center for Climate Modelling and Analysis [CGCM 3.1], Australian-based Commonwealth Scientific and Industrial Research Organization [CSIROMk3.5], National Institute for Environmental Studies [MIROC 3.2 medres], and National Center for Atmospheric Research [NCAR-CC $\mathrm{SM} 3]$ ), climate warming is projected to be between $3-6^{\circ} \mathrm{C}$ 


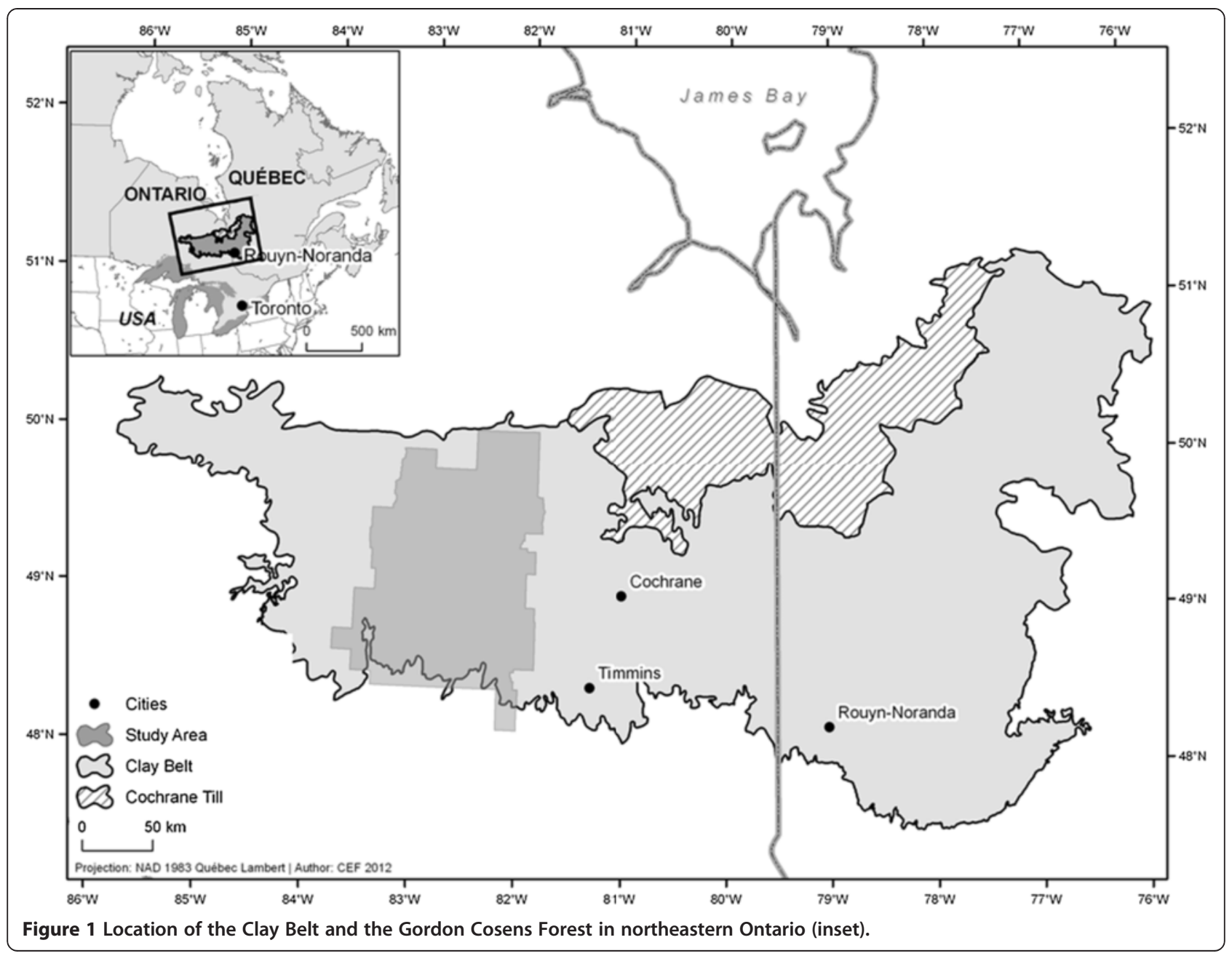

and precipitation is projected to increase by $10 \%-20 \%$ by the end of the 21st century (McKenney et al. 2010).

In the study area, fire frequency has diminished from a 100 -year cycle to an approximately 400-year cycle since the little Ice Age (ca. 1850; Bergeron et al. 2004). As a result of anthropogenic climate change, Bergeron et al. (2010) predict a doubling of fire frequency in this region by the end of the 21 st century.

\section{Map data}

Data for individual forest stands polygons, used to forecast the development of boreal forested peatlands, were retrieved from the Ontario ecosite classification system (Taylor et al. 2000). This classification seeks to classify the province's ecosystems, such as non forested uplands (prairie, cliff top, dunes), forested ecosystems (both upland and lowland), and non forested wetlands (marshes, swamps, fen, bogs). For forest polygons, ecosites are defined as homogeneous landscape areas (i.e. polygons typically 10-100 hectares) of common surficial deposits, soil moisture regime, soil texture, SOL thickness, humus form, and tree cover. Figure 2 illustrates the forest stand mosaic of the Gordon Cosens Forest, whereas Table 1 shows the size distribution of forest stand polygons. Ecosite classification is meant to be a practical tool for resource managers, and can be used for a variety of forest and site level applications including timber supply analysis, harvest planning, wildlife habitat studies and assessments, and successional studies.

The forest stand polygon data used in this study were retrieved from the 2004 forest inventory reassessment, the most recent reassessment available for the study area. The analysis of this inventory reveals that in 2004, organic deposits (i.e. surficial deposit consisting of a SOL $>40 \mathrm{~cm}$ thick) covered $42 \%$ of the study area, and nearly $70 \%$ of the area had moist to wet soils. While black spruce stands covered $55 \%$ of the study area, trembling aspen (Populus tremuloides Michx.) and mixed black spruce-trembling aspen stands covered 5\% and $25 \%$ of the area, respectively. Jack pine (Pinus banksiana 


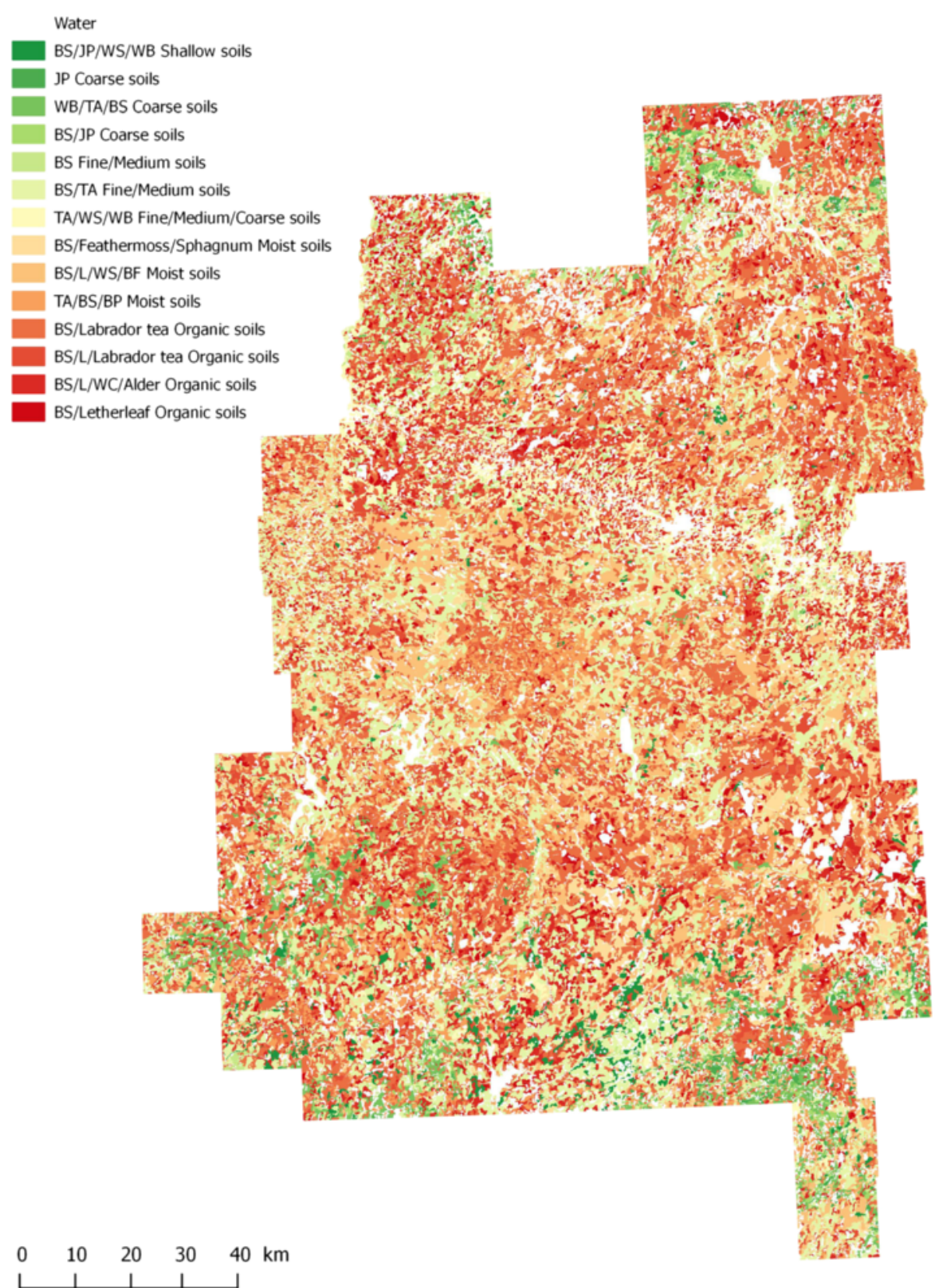

Projection: NAD 1983 | Author CEF 2014

Figure 2 Forest mosaic of the Gordon Cosens Forest. $B F=$ balsam fir, $B P=$ balsam poplar, $B S=$ black spruce, $J P=$ jack pine, $L=$ larch, $T A=$ trembling aspen, $\mathrm{WB}=$ white birch, $\mathrm{WC}=$ white cedar, $\mathrm{WS}=$ white spruce.

Table 1 Size and area distribution of polygons of the Gordon Cosens Forest map

\begin{tabular}{lll}
\hline Polygon area (ha) & Number of polygons & Total area $\left.\mathbf{( k m}^{\mathbf{2}}\right)$ \\
\hline$<1$ & $9402(11 \%)$ & $29(0.2 \%)$ \\
$1-10$ & $36030(41 \%)$ & $1702(9.8 \%)$ \\
$10-100$ & $38694(45 \%)$ & $11631(67.0 \%)$ \\
$>100$ & $2489(3 \%)$ & $1702(23.0 \%)$ \\
\hline
\end{tabular}

Lamb.), white spruce (Picea glauca Moench), and white birch (Betula papyrifera Marsh.) were the other dominant species of the regional landscape.

\section{Development of the paludification index}

Using static (e.g. surficial deposit and soil texture) and dynamic (e.g. moisture regime and SOL thickness) stand scale factors available from forest maps (Table 2; Taylor et al. 2000), we developed a dynamic paludification index 
Table 2 Paludification scores for static and dynamic stand scale factors

\begin{tabular}{|c|c|c|c|c|c|c|c|c|c|c|c|}
\hline \multicolumn{2}{|c|}{ Surficial deposit (D) } & \multicolumn{2}{|l|}{ Soil texture $(\mathrm{T})$} & \multicolumn{2}{|c|}{ Humus form $(\mathrm{H})$} & \multicolumn{2}{|c|}{$\begin{array}{l}\text { Soil organic layer } \\
\text { thickness (SOL) }\end{array}$} & \multicolumn{2}{|c|}{ Moisture regime $(\mathrm{M})$} & \multicolumn{2}{|c|}{ Overstorey (0) } \\
\hline Class & Score & Class $^{1}$ & Score & Class $^{1}$ & Score & Class $^{2}$ & Score & Class $^{3}$ & Score & Class & Score \\
\hline Rock & 0 & Rock & 0 & Mull & 0 & $0-9$ & 0 & Dry & 0 & Other spp. & 0 \\
\hline Aeolian & 1 & Sandy & 0 & Moder & 0 & $10-19$ & 1 & Moderately fresh & 0 & Black spruce & 1 \\
\hline Fluviatil & 1 & Coarse loam & 0 & Humic mor & 1 & $20-29$ & 1 & Fresh & 0 & & \\
\hline Fluvial till & 1 & Medium loam & 1 & Fibric mor & 1 & $30-39$ & 2 & Very fresh & 0 & & \\
\hline Clay till & 2 & Silty & 1 & Humic & 2 & $40-120$ & 2 & Moderately moist & 1 & & \\
\hline Lacustrine & 2 & Fine loam & 1 & Mesic & 2 & $>120$ & 2 & Moist & 2 & & \\
\hline \multirow[t]{3}{*}{ Organic } & 2 & Clay & 2 & Fibric & 2 & & & Very moist & 3 & & \\
\hline & & & & & & & & Wet & 4 & & \\
\hline & & & & & & & & Very wet & 5 & & \\
\hline
\end{tabular}

Each static and dynamic factor was divided into classes, each of which was attributed a score related to its paludification "power"; $0=$ null "power", 1 = low "power", 5 = high "power". Adding up the score of each factor, gives a Paludification Index that estimates the liability of each stand to paludification.

${ }^{1}$ According to Sims and Baldwin (1996).

${ }^{2}$ In $\mathrm{cm}$. In our paludification index, we used the median value of each class.

${ }^{3}$ According to Sims et al. (1989).

for each forest stand polygon. Each static and dynamic factor was divided into classes (2 to 9 according to site feature), each of which was attributed a score related to its paludification "power" (between 0 and $5 ; 0=$ null paludification "power" and $5=$ high paludification "power"). Table 2 lists the factor classes with their related paludification "power" score. Adding up the score of each factor, gives the paludification index, which describes the level of paludification of each forest stand polygon (hereafter referred to as stand). The maximum score an ecosite could achieve is 14 . The paludification index was calculated as follows:

$$
\mathrm{PI}=\text { Static factors }+ \text { Dynamic factors }
$$

or

$$
\mathrm{PI}=(D+T+H)+(S O L+M+O),
$$

where PI is the paludification index, $D$ is surficial deposit, $T$ is soil texture, $H$ is humus form, $S O L$ is soil organic layer thickness, $M$ is moisture regime, and $O$ is overstorey composition. Although we recognize the dynamic nature of surficial deposits and soil texture, we treated these factors as static because the transformation rates of these variables are slow relative to the projection time (i.e. 100 years) used in this study. Similarly, humus form was considered to be static because of its slow rate of transformation (Yu et al. 2001). Stands with a $P I \geq 13$ were classified as paludified, whereas stands with a $P I$ between $\geq 7$ and $<13$ were classified as nearly paludified. Stands with a $P I \leq 6$ were classified as not paludified. Although we recognize the possibility of interactions among variables and nonlinearity in the effects, the use of a simple index with linear effects was justified because of the lack of information about possible interactions among some variables.

Dynamic factors were allowed to vary over time according to certain rules. In the base index (i.e. the index not considering climate change or fire), SOL thickness increased with time, following peat accumulation rates determined by Lecomte et al. (2006) for nearby sites located in the Clay Belt of Quebec. According to Lecomte et al. (2006), for the past ca. 200 years the peat accumulation rate varied between 10 and $20 \mathrm{~cm}$ per century. Lecomte et al. (2006) also showed that peat tends to accumulate at a faster rate where $\mathrm{SOL}$ is $>20 \mathrm{~cm}$ deep. As a result, the base index was adjusted to allow stands with a median SOL depth $>20 \mathrm{~cm}$ to accumulate peat at a rate of $20 \mathrm{~cm}$ per century, whereas stands with SOL median depth $<20 \mathrm{~cm}$ we allowed to accumulate peat at a rate of $10 \mathrm{~cm}$ per century. In the same vein, stands with an initial SOL depth $<20 \mathrm{~cm}$ had their peat accumulation rate adjusted to $20 \mathrm{~cm}$ per century when their SOL depth reached $20 \mathrm{~cm}$. Simard et al. (2009) and Drobyshev et al. (2010) observed an important decline in tree growth when SOL depth is $20 \mathrm{~cm}$ or greater, further confirming the pertinence of the $20 \mathrm{~cm}$ cut off point. Furthermore, in the base index, moisture regime was allowed to vary in stands where soil texture was finer than medium loam, only if SOL depth was $\geq 20 \mathrm{~cm}$. Hence, in all cases when SOL depth reached $\geq 20 \mathrm{~cm}$, moisture regime stepped one class ahead. For example, stands with a fine loam soil texture and a moisture regime classified as Moist had their moisture regime changed to Very moist when their SOL depth reached $20 \mathrm{~cm}$.

In the index considering climate change, peat accumulation rate (hence SOL thickness) was allowed to vary according to an adaptation of the Peat Accumulation Model (PAM; Hilbert et al. 2000) made by Wu (2012). 
Wu (2012) modified PAM to study the response of peatland development and carbon cycling to climate change and to answer several research questions, among which was the following: How does peat accumulation respond to changes in precipitation and temperature? In its most basic form, PAM considers peat accumulation (i.e. SOL thickness) as a simple equation: "peat production minus the sum of oxic decomposition and anoxic decomposition equals peat accumulation" (i.e. change in SOL thickness $=$ peat production - peat decomposition). In Wu's (2012) adaptation of PAM, the peat accumulation rate in ombrotrophic bogs could decrease by up to $70 \%$ within the first 100 years following the initiation of climate change. In fact, Wu's (2012) estimation suggested that for the 30 year period between 2011 and 2040, which corresponds to a $1^{\circ} \mathrm{C}$ increase in temperature, peat accumulation rate would drop by $15 \%$. For the 30 year period between 2041 and $2070\left(2^{\circ} \mathrm{C}\right.$ increase in temperature) peat accumulation rate would drop by an additional $25 \%$. Finally, for the 30 year period between 2071 and 2100 $\left(3^{\circ} \mathrm{C}\right.$ increase in temperature) peat accumulation rate would drop by an additional $30 \%$. Hence, according to our estimations based on Wu's (2012) relationship between temperature increase and decrease in peat accumulation rate, this relationship fits the following equation:

$$
\begin{aligned}
\text { Peat }_{\mathrm{AR}}= & (16.0414 \times T)+\left(-5.7383 \times T^{2}\right) \\
& +\left(2.7230 \times T^{3}\right)
\end{aligned}
$$

where Peat ${ }_{A R}$ is the accumulation rate of peat in $\mathrm{cm} \cdot \mathrm{yr}^{-1}$ and $T$ the temperature $\left({ }^{\circ} \mathrm{C}\right)$ increase. As a result, the peat accumulation rate decreases rapidly to the point where the accumulation rate was negative (i.e. peat decomposition rate was greater than production rate). Consequently, a temperature increase between $3^{\circ} \mathrm{C}$ and $4^{\circ} \mathrm{C}$ results in a reduction of SOL thickness of approximately $0.5 \mathrm{~mm} \cdot \mathrm{yr}^{-1}$, between $4^{\circ} \mathrm{C}$ and $5^{\circ} \mathrm{C}$ a reduction of $1.8 \mathrm{~mm} \cdot \mathrm{yr}^{-1}$, and between $5^{\circ} \mathrm{C}$ and $6^{\circ} \mathrm{C}$ a reduction of $3.8 \mathrm{~mm} \cdot \mathrm{yr}^{-1}$. Hence, when a $4^{\circ} \mathrm{C}$ increase is reached, peat decomposition rate is greater than its production rate, leading to a reduction in SOL thickness. Although we recognize that this extension is simplistic and should be interpreted with greater caution, we believe this extension should be representative of the effect of temperatures increases beyond $3^{\circ} \mathrm{C}$ on peat accumulation rate and its effect on SOL thickness. Furthermore, although we acknowledge that ombrotrophic bogs and paludified forest support a different aboveground vegetation structure (i.e. shrubs- vs. tree-dominated aboveground vegetation for ombrotrophic bogs and paludified forests, respectively), we assumed that peat decomposition in ombrotrophic bogs and paludified forests would show similar responses to temperature increase.

From this information, we projected peat accumulation and SOL thickness according to three temperature increase scenarios (i.e. $+1^{\circ} \mathrm{C},+3^{\circ} \mathrm{C}$ and $+6^{\circ} \mathrm{C}$, which respectively correspond to $5 \%, 40 \%$ and $70 \%$ reduction in peat accumulation rate) and for four initial SOL thickness $(5 \mathrm{~cm}, 10 \mathrm{~cm}, 20 \mathrm{~cm}$, and $40 \mathrm{~cm})$. For each scenario, average temperature was progressively increased during the simulations so that by 2100 temperature increases amount to $+1^{\circ} \mathrm{C},+3^{\circ} \mathrm{C}$ and $+6^{\circ} \mathrm{C}$ relative to the average temperature as of 2004. For these four initial SOL thicknesses, peat accumulation rate varied according to Lecomte et al. (2006), i.e. where SOL is $<20 \mathrm{~cm}$ thick, peat accumulated at a rate of $10 \mathrm{~cm}$ per century, whereas where SOL is $>20 \mathrm{~cm}$ thick, peat accumulated at a rate of $20 \mathrm{~cm}$ per century. At each time step, SOL thickness was estimated as follow:

$$
\mathrm{SOL}_{\mathrm{t}}=\mathrm{SOL}_{\mathrm{i}}+\left(30 \times \text { Peat }_{\mathrm{ARt}}\right)
$$

where $\mathrm{SOL}_{\mathrm{i}}$ is the thickness of the soil organic layer at the beginning of the reference period and Peat ${ }_{\mathrm{ARt}}$ is the accumulation rate of peat for the reference period. Peat ${ }_{\text {ARt }}$ was calculated as follow:

$$
\text { Peat }_{\mathrm{ARt}}=\text { Peat }_{\mathrm{ARi}}-\left(\text { Peat }_{\mathrm{ARi}} \times\left(R_{\mathrm{t}} / 100\right)\right.
$$

where Peat ${ }_{\mathrm{ARi}}$ is the initial accumulation rate of peat and $R_{\mathrm{t}}$ is the reduction of peat accumulation rate for the period of reference, i.e. accumulation rate for each 30 year period. For each SOL thickness class (i.e. $5 \mathrm{~cm}$, $10 \mathrm{~cm}, 20$, and $40 \mathrm{~cm}$ ), we calculated peat accumulation rate and the SOL thickness for each time step under the three climatic scenarios (i.e. $+1^{\circ} \mathrm{C},+3^{\circ} \mathrm{C}$ and $+6^{\circ} \mathrm{C}$ ).

Finally, in the index considering both climate change and natural fire regime, we first projected forest paludification considering the current fire cycle of 400 years as determined by Bergeron et al. (2004). Then we projected forest paludification allowing the fire cycle to decrease according to projections made by Bergeron et al. (2010). In this sub-index, the fire cycle decreased to 300 years for 2011-2041, to 250 years for 2041-2071, and to 200 years for 2071-2100. Furthermore, based on our own observations, we considered that currently $50 \%$ of fire ignitions resulted in high-severity fires, i.e. fires that left $<5 \mathrm{~cm}$ of residual SOL over the mineral soil (Simard et al. 2007). In light of greater uncertainty surrounding the impact of the climate change on fire severity, we ran our projections considering three proportions of highseverity fires, i.e. $25 \%, 50 \%$ and $75 \%$. Furthermore, we considered that stands with SOL $>120 \mathrm{~cm}$ could not be submitted to high-severity fires because it is highly unlikely that a fire would leave $<5 \mathrm{~cm}$ of residual SOL over the mineral soil in such stands. At each time step, fire events and severity were randomly attributed to the forest stands of the study area.

The three indices were run in the following sequence: (1) base index, (2) base index + climate change, and (3) 
base index + climate change + natural fire regime modifications. This sequence allowed us to first explore the effect of climate change alone and then the combined effects of climate change and modifications of the fire regime on the potential for paludification of the forest stands of the study area.

\section{Results}

\section{Base paludification index}

According to the Ontario forest map data, $42.2 \%$ of the area of the Gordon Cosens Forest was already paludified in 2004 , whereas $57.8 \%$ of the area was not paludified (Table 3).

As paludification is a relatively slow process, the index did not forecast any change in the level of paludification of the territory for the 2041 time step compared to the current state of the Gordon Cosens Forest (Table 3). As an illustration, Figure 3 shows the slow but constant thickening of the SOL for four different initial SOL thickness scenarios. When initial SOL thickness was set at $5 \mathrm{~cm}$ or $10 \mathrm{~cm}$, SOL thickness projected for 2100 remained below $20 \mathrm{~cm}$ (Figure 3). However, when initial SOL thickness was set at $20 \mathrm{~cm}$, SOL thickness reached $30 \mathrm{~cm}$ around 2060 and nearly $40 \mathrm{~cm}$ in 2100 (Figure 2). Similarly, when initial SOL thickness was set at $40 \mathrm{~cm}$, SOL thickness reached $50 \mathrm{~cm}$ around 2060 and nearly $60 \mathrm{~cm}$ in 2100 (Figure 3). As a result, for the 2071 time step, the proportion of the study area occupied by nearly paludified stands increased from 0 to $11.7 \%$, whereas as that occupied by not paludified stands decreased to 46.1\% (Table 3); the proportion of the study area classified as paludified did not change. For the 2100 time step, the index forecasted that the proportion of the study area classified as nearly paludified increased to $26.4 \%$ (Table 3), while the proportion of area classified as not paludified decreased to $31.4 \%$. At this time step, nearly $70 \%$ of the forest stands of the Gordon Cosens Forest could be classified as paludified or nearly paludified, which corresponds to a $166 \%$ increase in the cover of paludified or nearly paludified areas.

\section{SOL thickness and climate change}

For every initial SOL thickness (i.e. $5 \mathrm{~cm}, 10 \mathrm{~cm}, 20 \mathrm{~cm}$ and $40 \mathrm{~cm}$ ), SOL thickness tended to increase with time for the $+1^{\circ} \mathrm{C}$ and $+3^{\circ} \mathrm{C}$ scenarios (Figure 4), the increase being greater for the $+1^{\circ} \mathrm{C}$ scenario. For the $+6^{\circ} \mathrm{C}$ scenario, an increase was observed until ca. 2060 when SOL thickness started to decrease. This tipping point corresponds to the moment where the temperature increase was ca. $4^{\circ} \mathrm{C}$. For the stands where initial SOL thickness was $5 \mathrm{~cm}$ or $10 \mathrm{~cm}$, the $+6^{\circ} \mathrm{C}$ scenario led to an almost complete disappearance of the SOL by 2100 . For the stands where initial SOL thickness was $20 \mathrm{~cm}$ or $40 \mathrm{~cm}$, the same scenario ended with SOL thickness similar to what was observed initially.

These negatives effect of climate change on peat accumulation resulted in no change in the proportion of the study area classified as paludified, nearly paludified and not paludified between 2011 and 2100 (Table 3).

\section{Combining climate change with natural fire regime}

The inclusion of the current fire cycle (400 years) in our index resulted in a slight decrease $(<6 \%)$ in the paludified area, regardless of the proportion of burnt stands submitted to high-severity fires (Figure 5a). Nonetheless, the decrease in paludified area was lower (ca. 2\%) when $25 \%$ of the burned stands were submitted to high-severity fires and steeper (ca. 6\%) when $75 \%$ were submitted to high-severity fires.

When the fire cycle was allowed to decrease according to the projections made by Bergeron et al. (2010), declines in paludified area was steeper for the three proportions of high-severity fires (Figure 4b). Declines in paludified area were ca. $9 \%, 25 \%$ and $40 \%$ for the $25 \%, 50 \%$ and $75 \%$ highseverity fires, respectively (Figure $5 \mathrm{~b}$ ).

\section{Discussion}

The boreal forest represents one of the Earth's largest biome, encompassing an area of approximately $14 \times$ $10^{6} \mathrm{~km}^{2}$ (Wieder et al. 2006). According to Bhatti et al. (2003), it is also one of the Earth's biomes most affected by global warming. About $25 \%$ of the boreal forest region is occupied by peatlands (Wieder et al. 2006), a large proportion of which are forested peatlands. Overall, peatlands store approximately 15\% of the Earth's terrestrial carbon (Gorham 1991; Lavoie et al. 2005). Consequently, at the global scale, any modifications to the natural fire regime in response to climate change may have a significant

Table 3 Paludification level (\% of the territory) of the Gordon Cosens forest according to the base index and the combination of the base index with climate change

\begin{tabular}{|c|c|c|c|c|c|c|c|}
\hline \multirow{2}{*}{$\begin{array}{l}\text { Paludification } \\
\text { level }\end{array}$} & \multirow[b]{2}{*}{ Current $^{1}$} & \multicolumn{3}{|c|}{ Base index } & \multicolumn{3}{|c|}{ Base index + climate change } \\
\hline & & 2041 & 2071 & 2100 & 2041 & 2071 & 2100 \\
\hline Not paludified & 57.8 & 57.8 & 46.1 & 31.4 & 57.8 & 57.8 & 57.8 \\
\hline Nearly paludified & 0.0 & 0.0 & 11.7 & 26.4 & 0.0 & 0.0 & 0.0 \\
\hline Paludified & 42.2 & 42.2 & 42.2 & 42.2 & 42.2 & 42.2 & 42.2 \\
\hline
\end{tabular}

'Based on the Ontario's 2004 Forest Resource Inventory. 


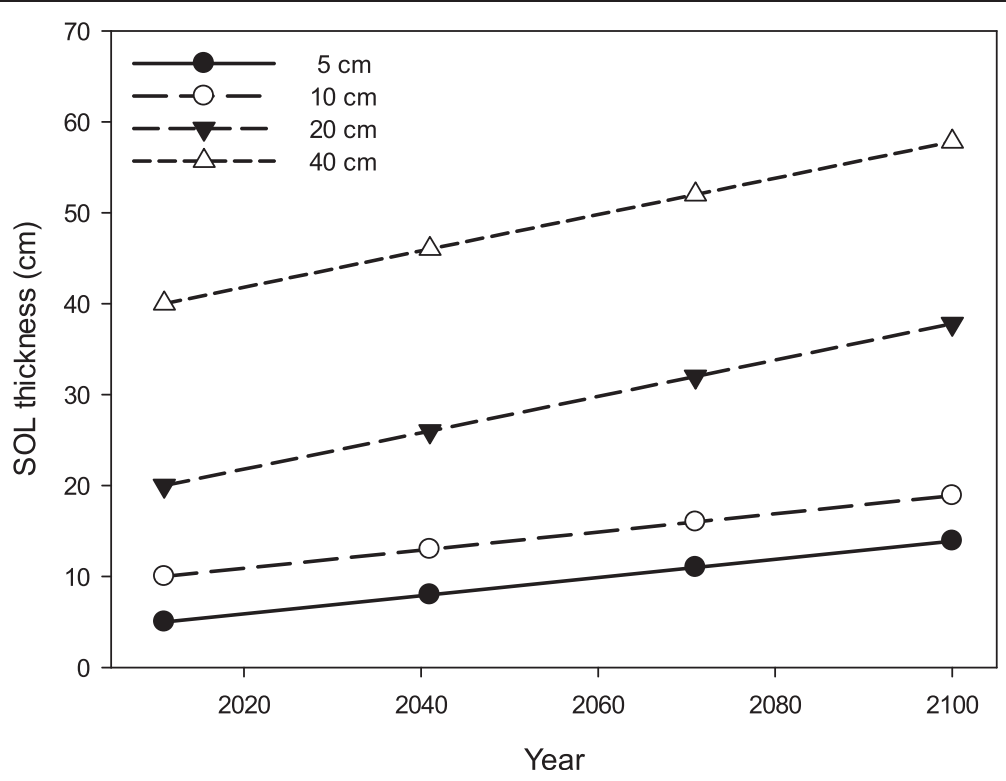

Figure 3 Soil organic layer (SOL) thickening with time without considering the effects of climate change. Initial $\mathrm{SOL}$ thickness (cm) is illustrated for four different scenarios: $5 \mathrm{~cm}, 10 \mathrm{~cm}, 20 \mathrm{~cm}$, and $40 \mathrm{~cm}$.

impact on the carbon sequestered in paludified forests. Our results suggest that in this context paludified forests may turn from $\mathrm{C}$ sink to atmospheric $\mathrm{C}$ source (in turn increasing atmospheric $\mathrm{CO}_{2}$ concentration and providing a positive feedback on climate warming) if the increase in forest productivity does not compensate for carbon losses.
However, it is important to note that the thick Sphagnum layer typical of paludified forests may protect SOL from drought and potential increasing depth of burn (and hence $\mathrm{CO}_{2}$ emissions), and therefore that a significant proportion of the territory has high potential to remain paludified (Magnan et al. 2012; Terrier et al. 2014a).
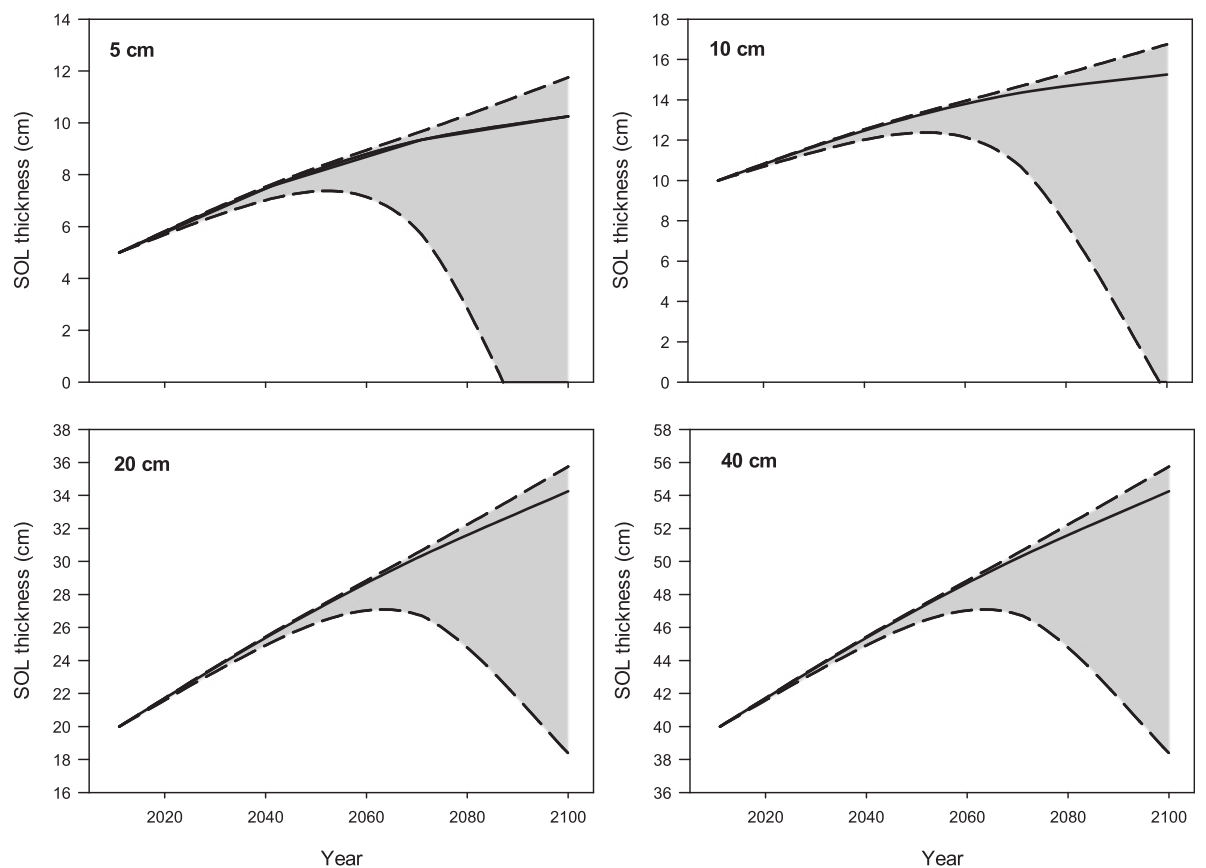

Figure 4 Soil organic layer $(\mathrm{SOL})$ thickness $(\mathbf{c m})$ variation with time in response to climate change. Each panel represents a different initial $\mathrm{SOL}$ thickness (i.e. $5 \mathrm{~cm}, 10 \mathrm{~cm}, 20 \mathrm{~cm}$, and $40 \mathrm{~cm}$ ) at the start of the projection. For each panel, upper dashed line $=+1^{\circ} \mathrm{C}$ scenario; middle solid line $=+3^{\circ} \mathrm{C}$ scenario; lower dashed line $=+6^{\circ} \mathrm{C}$ scenario. 

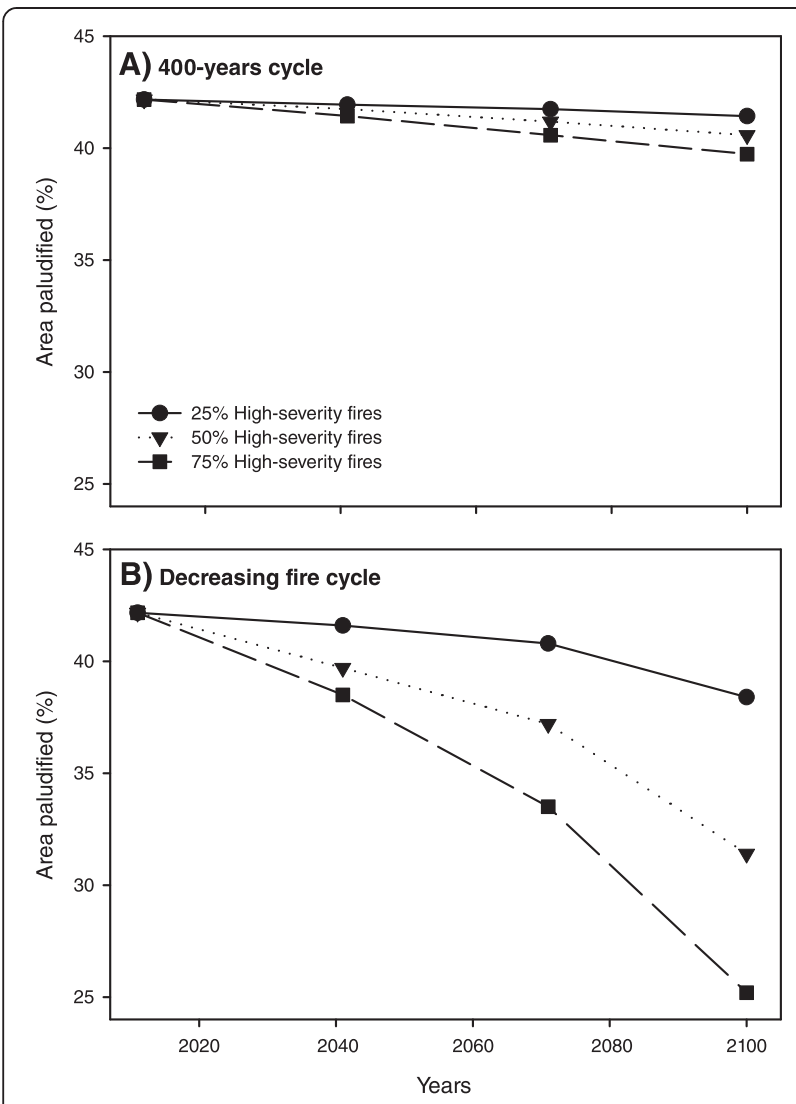

Figure 5 Projected effects of climate change and fire severity on paludified area for the period 2011-2100. A) Fire cycle was maintained at 400 years throughout the projection. B) Fire cycle was adjusted according to projections by Bergeron et al. (2010) for a region covering northeastern Ontario and northwestern Quebec; in 2041 , fire cycle $=300$ years; in 2071, fire cycle $=250$ years; in 2100, fire cycle $=200$ years.

The base paludification index produced slow but noticeable increases in proportion of the study area classified as paludified or nearly paludified. In the absence of fire in 2100 nearly $70 \%$ of the area of the Gordon Cosens Forest could be classified as nearly paludified (26\%) or paludified (42\%). This change is attributable to increased SOL thickness and concomitant change in moisture regime. Stands most susceptible to paludification were generally located on lacustrine surficial deposits or clay till, had fine textured soil (clay to coarse loam), a moisture regime classified as Moist to Very moist, SOL median depth of $20 \mathrm{~cm}$, and an overstorey comprised of black spruce (sometimes accompanied by trembling aspen) (data not shown). Over the projected time frame considered with this base index, most of the stands of the study area were classified as nearly paludified or paludified.

Furthermore, as expected, temperature increase and the concomitant reduction in peat accumulation rate had an effect on SOL thickness. For the $+1^{\circ} \mathrm{C}$ and $+3^{\circ} \mathrm{C}$ scenarios, SOL thickness increased with time, although at a slower rate than in the model not considering climate change. For the $+6^{\circ} \mathrm{C}$ scenario, however, peat accumulation ceased and SOL thickness started to decrease around the year 2060, indicating that the peat production rate was subsequently lower than its decomposition rate. In a long-term simulation, Ise et al. (2008) observed that a $4^{\circ} \mathrm{C}$ air temperature rise caused a $15 \%$ loss of soil organic carbon (measured in $\mathrm{kg} \mathrm{C} \cdot \mathrm{m}^{-2}$ ) for a reference period of 100 years, which corresponds to a $10 \mathrm{~cm}$ reduction in SOL thickness. This is similar to the difference we observed (ca. $15 \mathrm{~cm}$ ) between the $+1^{\circ} \mathrm{C}$ and the $+6^{\circ} \mathrm{C}$ scenarios. These results suggest that paludified stands (i.e. stands where SOL thickness $>40 \mathrm{~cm}$ ) will remain paludified in 2100 .

In consequence, the introduction of the effects of temperature increase in the paludification index did not produce any modifications in the proportion of the study area whether classified as paludified, nearly paludified or not paludified compared to the base index. Hence, despite increasing temperature between 2011 and 2100, the level of paludification of the study area did not change over time. Although our model did not consider the effects of changes in precipitation on paludification, a recent modeling study suggested that in the boreal forest of eastern Canada precipitation could increase by $10 \%-20 \%$ by the end of the 21 st century (McKenney et al. 2010). An increase in precipitation would logically lead to an increase in peat accumulation rate via the influence of higher water tables and a subsequent decrease in peat decomposition rate (Silvola et al. 1996; Ise et al. 2008). However, increased temperature is expected to lead to an increase in evapotranspiration, therefore leaving less moisture in the system (Soja et al. 2007; Wu 2012) and increasing risks of drought. A decrease in moisture availability in the system would, in turn, induce a lowering of the water table, a thickening of the oxic layer, and an increase in substrate temperature. Together these modifications would depress the peat accumulation rate, but more importantly, increase the peat decomposition rate, resulting in a steady SOL thickness over time. Therefore as two factors are acting in opposite directions (i.e. peat accumulation with time vs. increase in peat decomposition rate in response to climate change), the expected effects of climate change (not considering modifications to the current fire cycle) in our study area could result in a territory similar to the present in terms of paludified area.

Introducing wildfire in the index produced a quite different picture of the study area. Keeping the fire cycle constant and at the current level (i.e. 400 years) produced only a slight decrease in paludified area. However, allowing the fire cycle to decrease with time (as projected by Bergeron et al. 2010) reduced the paludified area by between $10 \%$ and $40 \%$ under the high-fire severity scenario. Decreased fire cycle and reduced paludified area 
could be attributed to the fact that the projected increase in precipitation (McKenney et al. 2010) may not fully compensate for increase in temperature, thus creating conditions that are more prone to fire occurrence (Terrier et al. 2013). Yet, we feel that an increase in the proportion of high-severity fires in areas already paludified is unlikely as a recent study conducted in the forested peatlands of the Clay Belt during an extreme drought year failed to detect any effect of drought on soil moisture (measured as gravimetric water content [\%]; Terrier et al. 2014a) where thick SOL $(>40 \mathrm{~cm})$ occurs. In the same study, the authors projected for the period 2071-2100 the effects of extreme drought on potential SOL depth of burn, and concluded that increase in drought conditions should not be sufficient to greatly modify SOL depth of burn in areas where thick SOL prevail with potential depth of burn up to $0.7 \mathrm{~cm}$ (Terrier et al. 2014a) for any individual fire event occurring between early spring and late fall. This resistance of SOL to drought and burn is related to the presence of Sphagnum species which hyaline cells stock large amounts of water (Silvola 1991) and limit its evaporation (Busby and Whitfield 1978), and therefore reduce potential depth of burn. However, Terrier's study (Terrier et al. 2014a) also suggested that in areas where SOL is $<40 \mathrm{~cm}$ and where Pleurozium schreberi is the dominant groundcovering moss, drought was able to depress soil moisture to the extent where they projected a potential depth of burn up to $3.2 \mathrm{~cm}$ for the period 2071-2100. These results suggest that areas that are in the process of being paludified exhibit a relatively high potential to remain unpaludified, and that those areas that are already paludified areas show a low potential for depaludification. These results are also in accordance with Magnan et al. (2012) who found no major changes in boreal peatlands despite evidence of slowed peat accumulation rates due to fire, and with Magnan et al. (2014) who showed that Sphagnumdominated bogs located in a maritime environment have persisted over millennia and that fires had few impacts on their vegetation dynamics.

Thus, at the landscape level, when fire cycle is kept constant at the current level, the slow rate of paludification results in a slight decrease in paludified area regardless of the proportion of high severity fires, suggesting either that the rate of peat accumulation in the index is too conservative, or that the current highly paludified landscape is not completely in balance with the current climate and fire regime (Payette 2001). Similarly, a decreasing fire cycle is likely to limit the development of paludified stands.

\section{Conclusions}

Overall, our models predict a slight (no modification to the current fire cycle) to moderate (decreasing fire cycle over time) decrease in area covered by paludified forests within the Gordon Cosens Forest in 2100. This might have several impacts for the forest industries of the Clay Belt as slower paludification rates imply greater forest productivity and potentially a greater potential for forest harvest.

Furthermore, at the global scale, increasing fire frequency in boreal paludified forests may have important consequences on carbon storage and climate if increases in forest productivity do not compensate for carbon losses. However, as the thick Sphagnum layer typical of paludified forests may protect soil organic layer from drought and deep burns, a significant proportion of the territory has high potential to remain a carbon sink.

In this context, our findings are supported by those of Terrier et al. (2014b) who in an area adjacent to our study area modeled the impacts of climate change on fire regime, vegetation dynamics and SOL depth of burn. They concluded that although climate change is likely to increase burn rates, the moist and cool conditions in these forests would prevent high depth of burn and the landscape would remain paludified.

This simple tool could be used by forest managers to forecast the development of paludified forests and to plan forest operations and conservation areas, and by policy makers to plan carbon management at the regional scale. Nonetheless, we recognize that in order to strengthen the predictions made by our index, the next step would be to construct a mechanistic model that includes sensitivity analysis as well as fire sub-indices that take into account drought and wildfire risk.

\section{Competing interests}

The authors declare that they have no competing interests.

\section{Authors' contributions}

BL developed the models, carried out the analysis, and wrote the manuscript, NJF and YB were instrumental in conceptualizing and refining the models, and in revising the manuscript. All authors read and approved the final manuscript.

\section{Acknowledgements}

This study was made possible by funding from the Ontario Ministry of Natural Resource. We thank Rachelle Lalonde for providing forest maps, Mélanie Desrochers for map production, and Aurélie Terrier for helpful discussion on fire modeling.

Received: 27 October 2014 Accepted: 20 January 2015

Published online: 30 January 2015

\section{References}

Bergeron Y, Gauthier S, Flannigan M, Kafka V (2004) Fire regimes at the transition between mixedwood and coniferous boreal forest in northwestern Quebec. Ecology 85:1916-1932

Bergeron Y, Cyr D, Girardin MP, Carcaillet C (2010) Will climate change drive 21st century burn rates in Canadian boreal forest outside of its natural variability: collating global climate model experiments with sedimentary charcoal data. Int J Wildl Fire 19:1127-1139

Bhatti JS, Van Kooten GC, Apps MJ, Laird LD, Campbell ID, Campbell C, Turetsky MR, Yu Z, Banfield E (2003) Forest management planning based on natural disturbance and forest dynamics. In: Burton PJ, Messier C, Smith DW, Adamowicz WL (eds) Towards sustainable management of the boreal forest. NRC Research Press, Ottawa, pp 799-855

Busby JR, Whitfield DWA (1978) Water potential, water content, and net assimilation of some boreal forest mosses. Can J Bot 56:1551-1558 
de Groot WJ, Pritchard JM, Lynham TJ (2009) Forest floor fuel consumption and carbon emissions in Canadian boreal forest fires. Can J For Res 39:367-382

Drobyshev I, Simard M, Bergeron Y, Hofgaard A (2010) Does soil organic layer thickness affect climate-growth relationships in the black spruce boreal ecosystem? Ecosystems 13:556-574

Dyrness CT, Norum RA (1983) The effects of experimental fires on black spruce forest floors in interior Alaska. Can J For Res 13:879-893

Environment Canada (2014) Canadian climate normals 1981-2010. http://www. climate.weather.gc.ca/climate_normals/index_e.html. Accessed 20 Oct 2014

Flannigan M, Logan KA, Amiro B, Skinner W, Stocks BJ (2005) Future area burned in Canada. Clim Change 72:1-16

Girardin MP, Mudelsee M (2008) Past and future changes in Canadian boreal wildfire activity. Ecol Appl 18:391-406

Gorham E (1991) Northern peatlands: role in the carbon cycle and probable responses to climatic warming. Ecol Appl 1:182-195

Greene DF, Macdonald SE, Cumming S, Swift L (2005) Seedbed variation from the interior through the edge of a large wildfire in Alberta. Can J For Res 35:1640-1647

Hilbert DW, Roulet N, Moore T (2000) Modelling and analysis of peatlands as dynamical systems. J Ecol 88:230-242

IPCC (2013) Climate change 2013: The physical science basis. In: Stocker TF, Qin D, Plattner G-K, Tignor M, Allen SK, Bashung J, Nauels A, Xia Y, Bex V, Midgley PM (eds) Contribution of Working Group I to the Fifth Assessment Report of the Intergovernmental Panel on Climate Change. Cambridge University Press, Cambridge, UK

Ise T, Dunn AL, Wofsy SC, Moorcroft PR (2008) High sensitivity of peat decomposition to climate change through water-table feedback. Nat Geosci 1:763-766

Jeglum JK (1991) Definition of trophic classes in wooded peatlands by means of vegetation types and plant indicators. Ann Bot Fenn 28:175-192

Lafleur B, Fenton NJ, Paré D, Simard M, Bergeron Y (2010a) Contrasting effects of season and method of harvest on soil properties and the growth of black spruce regeneration in the boreal forested peatlands of eastern Canada. Silva Fenn 45:799-813

Lafleur B, Paré D, Fenton NJ, Bergeron Y (2010b) Do harvest and soil type impact the regeneration and growth of black spruce stands in northwestern Quebec? Can J For Res 40:1843-1851

Lavoie M, Paré D, Bergeron Y (2005) Impact of global change and forest management on carbon sequestration on northern forested peatlands. Environ Rev 13:199-240

Lecomte N, Simard M, Bergeron Y, Larouche A, Asnong H, Richard PJH (2005) Effects of fire severity and initial tree composition on understorey vegetation dynamics in a boreal landscape inferred from chronosequence and paleoecological data. J Veg Sci 16:665-674

Lecomte N, Simard M, Fenton N, Bergeron Y (2006) Fire severity and long-term ecosystem biomass dynamics in coniferous boral forests of eastern Canada. Ecosystems 9:1215-1230

Magnan G, Lavoie M, Payette S (2012) Impact of long-term vegetation dynamics of ombrotrophic peatlands in northwestern Québec, Canada. Quat Res 77:110-121

Magnan G, Garneau M, Payette S (2014) Holocene development of maritime ombrotrophic peatlands of the St. Lawrence North Shore in eastern Canada. Quat Res 82:96-106

McKenney DW, Pedlar JH, Lawrence K, Gray PA, Colombo SJ, Crins WJ (2010) Current and projected future climatic conditions for ecoregions and selected natural heritage areas in Ontario, Climate Change Res. Rep. CCRR-016. Ontario Forest Research Institute, Ministry of Natural Resources, Sault Ste. Marie, ON, Canada

Payette S (2001) Les principaux types de tourbières. In: Payette S, Rochefort L (eds) Écologie des tourbières du Québec-Labrador. Les Presses de l'Université Laval, Québec, Québec, pp 39-89

Payette S, Garneau M, Delwaide A, Schaffhauser A (2013) Forest soil paludification and mid-Holocene retreat of jack pine in easternmost North America: Evidence for a climatic shift from fire-prone to peat-prone conditions. The Holocene 23:494-503

Riley JL (1994) Peat and peatland resources of northeastern Ontario. Ministry of Northern Development and Mines, Ontario Geological Survey. Misc. Paper No, 153

Silvola J (1991) Moisture dependence of $\mathrm{CO}_{2}$ exchange and its recovery after drying in certain boreal forest and peat mosses. Lindergia 17:5-10
Silvola J, Alm J, Ahlholm U, Nykanen H, Martikainen PJ (1996) $\mathrm{CO}_{2}$-fluxes from peat in boreal mires under varying temperature and moisture conditions. J Ecol 84:219-228

Simard M, Lecomte N, Bergeron Y, Bernier PY, Paré D (2007) Forest productivity decline caused by successional paludification of boreal soils. Ecol Appl 17:1619-1637

Simard M, Bernier PY, Bergeron Y, Paré D, Guérine L (2009) Paludification dynamics in the boreal forest of the James Bay Lowlands: effect of time since fire and topography. Can J For Res 39:546-552

Sims RA, Baldwin KA (1996) Forest humus forms in northwestern Ontario. Natural Resources Canada, Canadian Forest Service, Great Lakes Forestry Centre, Technical Report TR-28

Sims RA, Towill WD, Baldwin KA, Wickware GM (1989) Field guide to the forest ecosystem classification for northwestern Ontario, Forest Canada and Ontario Ministry of Natural Resources., p 191

Soil Classification Working Group (1998) The canadian system of soil classification, 3rd edn. Agriculture and Agri-Food Canada Publication 1646, Canada

Soja AJ, Tchebakova NM, French NHF, Flannigan MD, Shugart HH, Stocks BJ, Sukhinin Al, Parfenova El, Chapin FS III, Stackhouse PW (2007) Climateinduced boreal forest change: Predictions versus current observations. Global Planet Change 56:274-296

Taylor KC, Arnup RW, Merchant BG, Parton WJ, Nieppola J (2000) A field guide to forest ecosystems of Northeastern Ontario, 2nd edn. Queen's Printer for Ontario, Canada

Terrier A, Girardin MP, Périé C, Legendre P, Bergeron Y (2013) Potential changes in forest composition could reduce impacts of climate change on boreal wildfires. Ecol Appl 23:21-35

Terrier A, de Groot WJ, Girardin MP, Bergeron Y (2014a) Dynamics of moisture content in spruce-feather moss and spruce-Sphagnum organic layers during an extreme fire season and implications for future depths of burn in Clay Belt black spruce forests. Int J Wildl Fire 23:490-502

Terrier A, Girardin MP, Cantin A, de Groot WJ, Anyomi KA, Gauthier S, Bergeron Y (2014b) Disturbance legacies and paludification mediate the ecological impact of an intensifying wildfire regime in the Clay Belt boreal forest of eastern North America. J Veg Sci doi:10.1111/jvs.12250.

van Bellen S, Garneau M, Bergeron Y (2010) Impact of climate change on forest fire severity and and consequences for carbon stocks in boreal forest stands of Quebec, Canada: A synthesis. Fire Ecol 6:16-44

Veillette JJ (1994) Evolution and paleohydrology of glacial lakes Barlow and Ojibway. Quat Sci Rev 13:945-971

Wieder RK, Vitt DH, Benscoter BW (2006) Peatlands and the boreal forest. In: Wieder RK, Vitt DH (eds) Boreal peatland ecosystems. Springer, New York, NY, pp 1-8

Wu J (2012) Response of peatland development and carbon cycling to climate change: a dynamic system modeling approach. Environ Earth Sci 65:141-151

Yu Z, Campbell ID, Vitt DH, Apps MJ (2001) Modelling long-term peatland dynamics. I. Concepts, review, and proposed design. Ecol Model 145:197-210

\section{Submit your manuscript to a SpringerOpen ${ }^{\circ}$ journal and benefit from:}

- Convenient online submission

- Rigorous peer review

- Immediate publication on acceptance

- Open access: articles freely available online

- High visibility within the field

- Retaining the copyright to your article

Submit your next manuscript at $>$ springeropen.com 